\title{
Kansei Engineering Modeling for Getuk Goreng Packaging Innovation Based on Social Media Trends
}

\author{
Hety Handayani Hidayat ${ }^{1}$, Rifah Ediati ${ }^{2}$, Nur Wijayanti ${ }^{3}$ and Tiyan Saputra \\ \{hety.hidayat@unsoed.ac.id ${ }^{1}$,rifah_bee@yahoo.com².nut.wijayanti@unsoed.ac.id\} \\ Jenderal Soedirman University, Banyumas, Central Java, Indonesia
}

\begin{abstract}
One of Banyumas featured SME's products is Getuk Goreng. However, the sales of Getuk Goreng has decreased in recent years. Hence, it needs some innovation in order to increase the product's added value. On the other hand, consumer's opinion in recent years can easily be found through social media. Social media has evolving as the platforms for observing reliable consumers expressions of opinions, feelings and thoughts. This expression can be basic for sustainable innovation in industry including Getuk Goreng SME because its can adjust to the trends quickly and actually. Aware of the problems and opportunities, this study aims to design the development of Getuk Goreng packaging design based on social media trends. Kansei Engineering was used to bridge the social media data into definite design parameters. The methodology includes information retrieval from Twitter as Kansei words, determination of packaging design attributes, processing semantic differential data from 200 respondents by Factor Analysis (FA) and PLS (Partial Least Square) to design recommended packaging designs. This study resulting that costumer eager the Getuk Goreng packaging with an eco-friendly concept design. It was made from palm leaves, with the shape of hexagonal, and small in size (netto: 500 gram). The other packaging properties recommended were natural in color, the front side should be equipped with window, and it shouldn't handle.
\end{abstract}

Keywords: Getuk Goreng packaging, Kansei engineering, Social Media 


\section{Introduction}

Getuk Goreng or fried getuk is one of SME's (Small and Medium Enterpises) featured products in the form of agricultural processed commodity and specialty of Banyumas Regency since 1918 until recently. Getuk Goreng is said as a featured product since it has certain characteristics and uniqueness and competitiveness, absorb surrounding workforce, and is environmentally friendly-oriented as a featured commoduty in Green Marketing [1]. This traditional dish is made of Banyumas Regency-specific cassava with its main production center in Sokaraja District. In addition to its good and typical taste, Getuk Goreng is nutritious to be a source of energy. Every piece of 1 Getuk Goreng contains energy 69.38 calorie and protein 0.49 gram. Every 100 gram of Getuk Goreng contains energy 561 calorie and protein 25.5 gram [2].

The production of Getuk Goreng in some SMEs in Sokaraja District plays a fairly important role for local economy. This business has been one of income sources and also creates job opportunities for local people in Sokaraja District [3]. Yet in its development, this business encounters problems. One of the problems encountered in Getuk Goreng industry in Sokaraja Industry is a fairly significant decrease in terms of number of business units, production volume, and number of workforce. The 2016 data from the Office for Commerce, Industry and Cooperative of Banyumas Regency indicated that the business units, number of workforce, and production volume in 2012 were 69 units, 587 people, and 3,055 tons respectively. Meanwhile, in 2016 they were 37 units, 386 people, and 2,750 tons respectively.

Some of these problems arise due to tight competition in its marketing and lack of innovation in developing Getuk Goreng pack as an MSE's featured product. In terms of the tight competition, in addition to being tighter, the competition also comes from both fellow getuk goreng and other merchandise actors. This results in uncertain economic state of craftsmen and decreased number of products purchased by customers [4]. In addition to its relatively simple production, Getuk Goreng is marketed using a besek (bamboo woven container) at varied sizes (generally 0.5 and $1 \mathrm{~kg}$ ) [5]. Even until recently, this besek is used to pack Getuk Goreng with no further innovation, in terms of both its material and appearance, thus making it look monotonous. 
One key to dealing with these problems is to develop Getuk Goreng product. Once applied, this new innovation to Getuk Goreng product pack could be one way to win the competition with other businesses and to improve the marketing. Hermawan Kartajaya, a marketing expert, says that technology has allowed packaging to change its function. It used to be said that packaging protects what it sells, but now, packaging sells what it protects [6]. Design development refers to such attributes as apperance, taste, and function of products based on customer's needs [7]. Nevertheless, this development still needs to consider and minimize possible environmental loss impacts [8][9][10]. Even until today, Getuk Goreng product packaging still serves as an icon of SME's product with green packaging concept. Customer's environmental awareness has received a progressive attention in marketing and customer behavior (Green marketing) literature. Currently, customers have changed into those with greater care to the environment. This becomes an opportunity for companies to design environmentally friendly packaging as what customers demand while still maintaining the specialty of Getuk Goreng product.

One opportunity from which customer's wish and expectation can be explored real time and easily is via social media. Users in social media enjoy their activities, including their complaint on certain products or company's services [11]. One of the most-used social networks in Indonesia and even the world is Twitter. Indonesia is ranked at the first place for the most Twitter users in Asia and sixth globally. According to data, $2.41 \%$ of its total $237,556,363$ population are Twitter users. Twitter holds a concept to spread information briefly, compactly, and real time using less than 140 characters [12]. Based on the data from internetlivestats.com, in 2019 the number of active Twitter users reached 350 millions with the number of tweets sent reaching up to 8 thousands/second. 
Basically, customer's emotional need of a service product gets more and more dominant. Strengthening emotion, feeling, and creativity and innovative aspects is the key to improving customers' acceptance of a product. In designing a product packaging to attract customers, it is necessary to have some knowledge on the impression left by the product in its customers and users [9]. One of many methods employed to discover customer's expectation and need is Kansei Engineering. Kansei Engineering is a method to develop a product based on customer's impression, feeling, and expectation of a modeled product and it translates it into design parameters [13]. Kansei Engineering is considered to have some strengths compared to other similar methods for it has the ability to translate customers' emotional need into concrete design parameters using certain techniques [14]. Based on the problems and opportunities as explained earlier, this research aimed at developing a packaging design for Getuk Goreng based on customers' kansei from social media trend.

\section{Methodology}

This research was conducted for 7 months from October 2019 through April 2020. The data were crawled from twitter at the Agriculture Technology Laboratory of Agriculture Faculty. However, the data from respondents were collected around Getuk Goreng production and merchandise centers in Sokaraja District, Banyumas Regency.

This study uses a kansei engineering approach. Kansei engineering bridges consumer desires into a concrete design of a product or service [15]. The Kansei word used is in the form of consumer feelings which are extracted from twitter data regarding opinions and trends in eco-friendly packaging. Furthermore, a preference level tester is carried out on the concept card with a semantic differential questionnaire. Because the population is not known, the respondent is taken using the following formula:

$$
\begin{aligned}
& n=\left[\frac{Z_{\alpha / 2}}{E}\right]^{2} \\
& n=\left[\frac{1,96}{0,2}\right]^{2} \\
&=96 \text { respondents } \\
& \text { Dimana : } \\
& \mathrm{n} \quad: \text { number of respondents }
\end{aligned}
$$


$\mathrm{Z}_{\alpha / 2} \quad$ : the standard value lists outside the normal standard of how the confidence level $(\alpha=95 \%)$

E : the level of provision used by expressing the maximum error magnitude $20 \%$.

Thus the required number of respondents is at least 96 people. In this study, there were 200 respondents who were willing to participate. Accordingly, then

considered more than sufficient to represent the expected model. Even some previous research related to kansei such as research on cramic souvenir design involved 40 respondents [16] and design development to improve sustainable tourism which collected data from 143 respondents [17]Then, the data generated from the respondents were analyzed multivariately using Factor Analysis (FA) and PLS (Partial Least Square) with XLStat 2020. Results of both were used as the basis to design the development of Getuk Goreng ecofriendly packaging which had the possibility of being applied.

\section{Result and Discussion}

\subsection{Determination of Kansei Words}

This research had a final objective of obtaining an eco-friendly secondary packaging design recommendation for Getuk Goreng as a featured SME's product based on emotion/kansei words from the customers. The issue trend regarding eco-friendly packaging in tweets which took the form of opinions from Twitter users globally in English served as the basis to determine Kansei Words in this research. The structure identification of kansei words was based on 4510 tweet data (Table 2) from 18 keywords search (interview with 3 packaging experts, 2 Getuk Goreng business owners, and 10 Getuk Goreng customer participants) (Table 1). The tweet data were processed and identified by making cloudwords (Figure 1) using term frequency method through coding in RStudio application.

Table 1. Keywords search for retrieving data tweet process

\begin{tabular}{llll}
\hline No. & Keywords & No. & Keywords \\
\hline 1 & Back to nature packaging & 9 & Sustainable packaging \\
2 & Food grade packaging & 10 & Biodegradable packaging \\
3 & Zero waste packaging & 11 & Recycle packaging \\
4 & Minimalize packaging & 12 & Handmade packaging \\
5 & Green packaging & 13 & Ecofriendly packaging \\
6 & Traditional packaging & 14 & Renewable packaging \\
7 & Natural packaging & 15 & Traditional food packaging \\
\hline
\end{tabular}




\begin{tabular}{llll}
\hline 8 & UMKM packaging & 16 & Eco-packaging \\
\hline
\end{tabular}

Table 2. The sample of raw data tweet

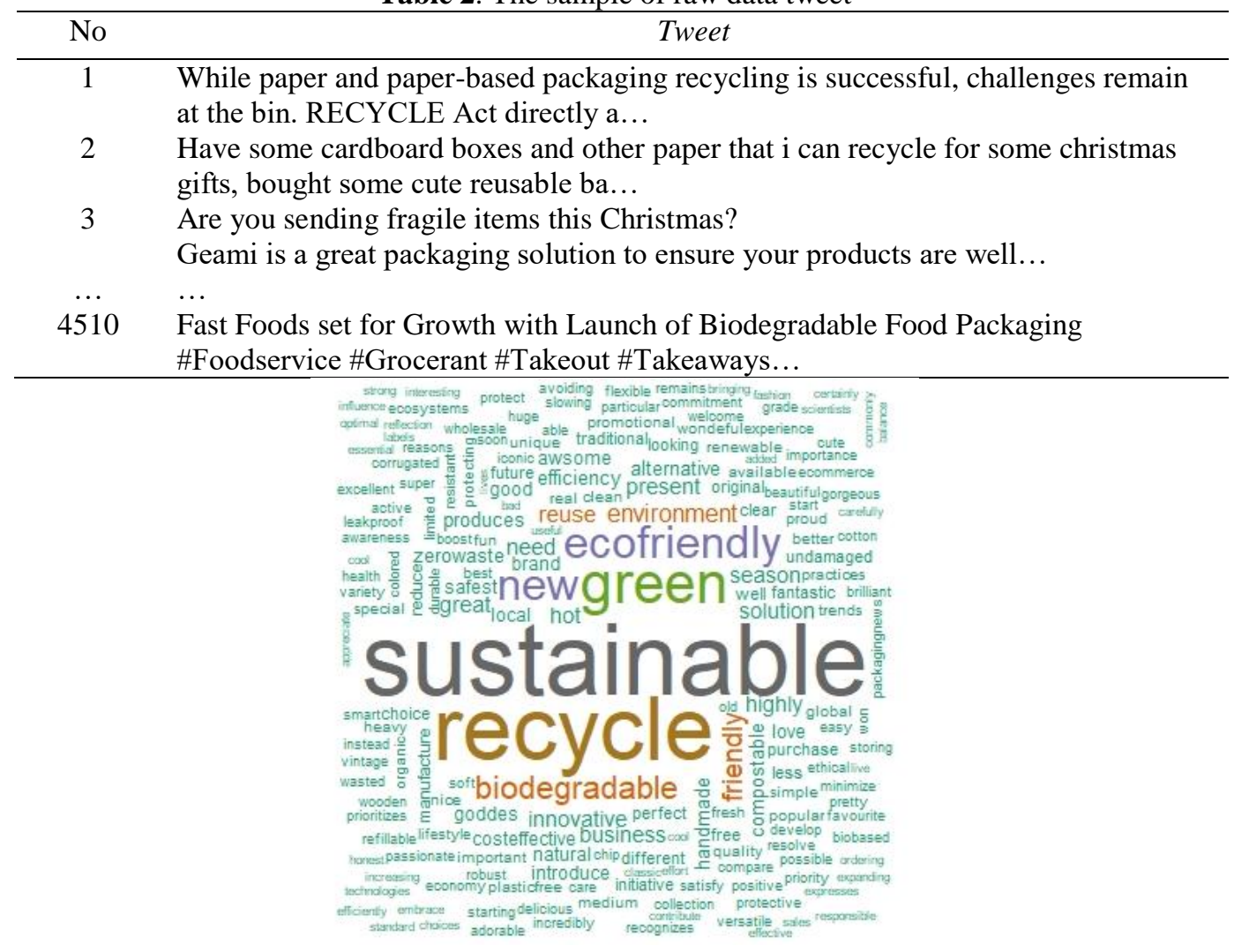

Fig. 1. Cloudswords of keywords tweet structure.

Figure 1 was the structure of kansei words based on reference frequency; the greater the word size, the more frequently for it to be referred to by Twitter users in tweets and to be deemed most important. We could see in Figure 1 that what had been the subjects regarding eco-friendly packaging from Twitter users globally were about the materials of the packaging itself, in reference to such words as sustainable, recycle, green, ecofriendly, etc. The materials used was the materials which supported the environment ecosystem sustainability and did not pollute nor damage the environment. This was tightly related to the green marketing currently massively promoted in the world of marketing. The importance of treating the nature and environment as the balancing power in winning competition was highlighted even further in current marketing era. In marketing, the environment conservation-based one was the real development and a potential and strategic opportunity with multiplier effect for both business actors and the community as users. 
Nowadays, we lived in an industrial era and the community though critically. Environment issues could not be separated from our monitoring of such a situation and condition. This was in line with previous studies which showed that customer's level of knowledge on environment (high or low) moderated the process of forming intention to buy eco-friendly product. This indicated that customers with high or low knowledge on environment had different intention-to-buy [18]. The research result showed that in this research the obtained indicated that social influence, recycling participation, environmental message exposure through media and value preceived by customers simultaneously had a significant influence on eco-friendly product purchasing behavior.

Table 3. Kansei words

\begin{tabular}{clclcl}
\hline No. & Kansei Words & No. & Kansei Words & No. & Kansei Words \\
\hline 1 & Sustainable & 11 & Good & 21 & Special \\
2 & Ecofriendly & 12 & Natural & 22 & Funny \\
3 & Innovative & 13 & Different & 23 & Heavy \\
4 & Season & 14 & Clear & 24 & Organic \\
5 & Great & 15 & Original & 25 & Wonderful \\
6 & Efficient & 16 & Fantastic & 26 & Easy \\
7 & Handmade & 17 & New & 27 & Beautiful \\
8 & Safety & 18 & Traditional & 28 & Protecting \\
9 & Economic & 19 & Unique & 29 & Colorful \\
10 & Local & 20 & Simple & 30 & Perfect \\
\hline
\end{tabular}

30 kansei words (Table 3) were selected from the structure of kansei words in Figure 1 and those words with similar meaning were grouped and elimination was made based on the frequency and matching with Getuk Goreng packaging. The chosen kansei words in Table 3 which had represented the characteristics of Getuk Goreng eco-friendly packaging as SME's featured product were then structured into a Semantic Differential scale with 5 scoring, the lowest being 1 which indicated "negative" and the highest being 5 which indicated "positive" (Table 4).

Table 4. Semantic differential questionnner

\begin{tabular}{|c|c|c|c|c|c|c|}
\hline Kansei Words & 1 & 2 & 3 & 4 & 5 & Kansei Words \\
\hline Unsustainable & & & & & & Sustainable \\
\hline Unfriendly & & & & & & Ecofriendly \\
\hline Uncreative & & & & & & Innovative \\
\hline Decondition & & & & & & Season \\
\hline Amateur & & & & & & Great \\
\hline Useless & & & & & & Efficient \\
\hline Automatic & & & & & & Handmade \\
\hline Danger & & & & & & Safety \\
\hline
\end{tabular}




\begin{tabular}{cccccccc}
\hline Kansei Words & 1 & 2 & 3 & 4 & 5 & \multicolumn{1}{c}{ Kansei Words } \\
\hline Unprofitable & & & & & & Economic \\
$\ldots$ & & & & & \\
Imperfect & & & & Perfect \\
\hline
\end{tabular}

\subsection{Determination of Packaging Design Attribute}

The determination of Getuk Goreng eco-friendly packaging design attribute/ element (Table 5) was based on the result of field survey on similar packaging sample which could be recommended and possibly be used for Getuk Goreng.

Table 5. Attributes and Catrgories of Packaging

\begin{tabular}{cll}
\hline No & \multicolumn{1}{c}{ Attribute } & \multicolumn{1}{c}{ Category } \\
\hline 1 & Material & Bamboo \\
& & Palm Leaves \\
2 & Shape & Cube \\
& & Beam \\
& Tube \\
& & Hexagonal \\
& & Pouch \\
& & Small \\
3 & Size & Medium \\
& & Big \\
& & Original \\
& & Colorfull \\
4 & Basic Color & One side \\
& & Twisted around \\
5 & Label Placement & Ban \\
& & Natural rope \\
6 & Accessories & Window \\
& & Handle \\
& & Non-handle
\end{tabular}

The selected packaging design attributes and categories in Table 5 were then used as the materials to structure 13 packaging specimens (Table 6) as a stimulant using Orthogonal Designs using IBM SPSS Statistics 25.0. The minimum number of stimuli was equal to the difference between categories with attributes added with one [19]. Then, the 13 specimens in Table 6 were manifested into a concept card as in Figure 2.

Table 6. Concept cards

\begin{tabular}{clcccccc}
\hline $\begin{array}{c}\text { Card } \\
\text { ID }\end{array}$ & Material & Shape & Size & $\begin{array}{c}\text { Basic } \\
\text { color }\end{array}$ & $\begin{array}{c}\text { Label } \\
\text { Placement }\end{array}$ & Accessories & Handling \\
\hline 1 & $\begin{array}{l}\text { Palm } \\
\text { Leaves } \\
\text { Palm }\end{array}$ & Hexagonal & Small & Original & One side & Natural rope & No handle \\
2 & Cube & Medium & Colorful & Twisted & Natural rope & handle \\
\hline
\end{tabular}




\begin{tabular}{|c|c|c|c|c|c|c|c|}
\hline $\begin{array}{c}\text { Card } \\
\text { ID }\end{array}$ & Material & Shape & Size & $\begin{array}{l}\text { Basic } \\
\text { color }\end{array}$ & $\begin{array}{c}\text { Label } \\
\text { Placement }\end{array}$ & Accessories & Handling \\
\hline & leaves & & & & around & & \\
\hline 3 & Bamboo & Cube & Medium & Original & One side & Window & handle \\
\hline 4 & Bamboo & Tube & Small & Original & One side & Window & handle \\
\hline 5 & Bamboo & Pouch & Small & Colorful & One side & Window & handle \\
\hline 6 & Bamboo & Cube & Medium & Original & One side & Window & No handle \\
\hline 7 & $\begin{array}{l}\text { Palm } \\
\text { Leaves }\end{array}$ & Tube & Small & Colorful & One side & $\begin{array}{l}\text { Modern } \\
\text { ribbon }\end{array}$ & No handle \\
\hline $\begin{array}{l}\ldots \\
13\end{array}$ & Bamboo & $\begin{array}{c}\cdots \\
\text { Hexagonal }\end{array}$ & $\stackrel{\ldots}{\text { Medium }}$ & Colorful & $\begin{array}{c}\ldots \\
\text { Twisted } \\
\text { around }\end{array}$ & $\begin{array}{c}\text { ‥ } \\
\text { Modern } \\
\text { ribbon }\end{array}$ & No handle \\
\hline
\end{tabular}

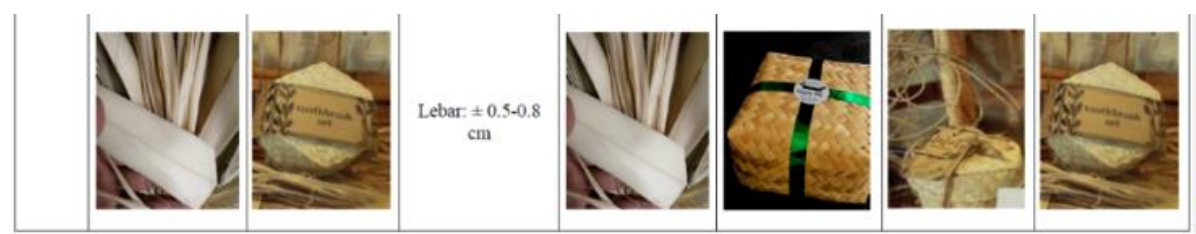

Fig. 2. Example of concept card visualization (Card No. 1)

\subsection{Designing Packaging Design Development}

Designing a new Getuk Goreng packaging design was based on the result of multivariate mathematical calculation analysis of semantic differential questionnaire data. The data from 200 participants, with a proportion of $67.5 \%$ of them being college students and $32.5 \%$ of them being general society, were recapitulated by averaging the entire data using Microsoft Excel 2019 manually (Table 7). Furthermore, these recapitulated data were used in a multivariate analysis.

Table 7. Result of Respondent's Preferences

\begin{tabular}{clrrrrr}
\hline \multirow{2}{*}{ No } & \multirow{2}{*}{ Kansei Words } & \multicolumn{5}{c}{ Concep Cards } \\
\cline { 3 - 7 } & & 1 & 2 & 3 & $\ldots$ & 13 \\
\hline 1 & Sustainable & 4.05 & 4.01 & 3.99 & $\ldots$ & 4.02 \\
2 & Ecofriendly & 4.50 & 4.12 & 4.15 & $\ldots$ & 3.90 \\
3 & Innovative & 4.18 & 4.10 & 3.99 & $\ldots$ & 4.22 \\
4 & Season & 3.29 & 3.73 & 3.41 & $\ldots$ & 3.98 \\
5 & Great & 3.83 & 4.06 & 3.79 & $\ldots$ & 3.98 \\
6 & Efficient & 3.99 & 4.09 & 4.21 & $\ldots$ & 3.97 \\
7 & Handmade & 4.29 & 4.08 & 4.30 & $\ldots$ & 4.10 \\
8 & Safety & 4.25 & 4.11 & 4.24 & $\ldots$ & 3.94 \\
9 & Economic & 4.06 & 3.97 & 3.92 & $\ldots$ & 3.87 \\
10 & Local & 4.13 & 3.95 & 3.59 & $\ldots$ & 4.08 \\
11 & Good & 4.20 & 4.15 & 4.11 & $\ldots$ & 4.10 \\
$\ldots$ & & $\ldots$ & $\ldots$ & $\ldots$ & $\ldots$ & $\ldots$ \\
\hline
\end{tabular}




$\begin{array}{lllllll}30 & \text { Perfect } & 3.69 & 3.75 & 3.74 & \ldots & 3.89\end{array}$

The first multivariate analysis was performed, i.e. Factor Analysis (FA). This multivariate analysis was done to give a description of emotion concept into Getuk Goreng packaging specimen structure, in which there was a relation between attributes. Factor Analysis (FA) was used to find the number of new factors and provided a description of relation between specimen and emotion. Factor Analysis (FA) in the research was carried out using XLStat 2020 software by involving the average recapitulation of participant data as the analysis materials. The analysis was done using varimax rotation to obtain a more accurate score. Based on Factor Analysis (FA) calculation, some new factors $(\mathrm{F})$ were obtained as shown in Table 8.

Table 8. Constructed Factor $(\mathrm{F})$

\begin{tabular}{lcccccc}
\hline & F1 & F2 & F3 & F4 & F5 & F6 \\
\hline Eigenvalue & 9.94 & 7.44 & 3.10 & 2.33 & 1.60 & 1.45 \\
Variability (\%) & 33.13 & 24.80 & 10.33 & 7.78 & 5.35 & 4.84 \\
Cumulative (\%) & 33.13 & 57.93 & 68.26 & 76.04 & 81.39 & 86.23 \\
\hline
\end{tabular}

There waere eigenvalue and variability values shown in Table 8 . The cumulative row showed acumulation up to F5 of $81.39 \%$, meaning the F1 to F5 values had represented the data analysis or they had an influence on emotion. This referred to a previous study which also used FA to explain that a cumulative level value greater than $80 \%$ had represented the data analysis, and five new factors were obtained and called as F1, F2, F3, F4, and F5 [20][21]. If the five new factors above were analyzed to determine the emotion value, different value variations would be obtained in each emotion. This was shown in Table 9 which indicated the magnitude of correlation between the five factors with emotion.

Table 9. Factor Analysis Result

\begin{tabular}{clcccc}
\hline No. & \multicolumn{1}{c}{ Variable } & Factor 1 & Factor 2 & $\ldots$ & Factor 5 \\
\hline 1 & Sustainable & 0.230 & -0.392 & $\ldots$ & 0.144 \\
2 & Ecofriendly & -0.056 & -0.780 & $\ldots$ & 0.541 \\
3 & Innovative & 0.927 & -0.269 & $\ldots$ & 0.037 \\
4 & Season & 0.334 & 0.519 & $\ldots$ & -0.283 \\
5 & Great & 0.796 & 0.215 & $\ldots$ & 0.311 \\
6 & Efficient & 0.330 & -0.310 & $\ldots$ & -0.014 \\
7 & Handmade & -0.090 & -0.857 & $\ldots$ & -0.118 \\
8 & Safety & 0.212 & -0.845 & $\ldots$ & 0.180 \\
9 & Economic & 0.011 & -0.607 & $\ldots$ & 0.124 \\
10 & Local & 0.413 & -0.218 & $\ldots$ & 0.014 \\
11 & Good & 0.692 & -0.430 & $\ldots$ & 0.006 \\
$\ldots$ & $\ldots$ & $\ldots$ & $\ldots$ & $\ldots$ & $\ldots$ \\
30 & Perfect & 0.718 & -0.032 & $\ldots$ & -0.473 \\
\hline
\end{tabular}


The minimum value determined in the research was 0.40 to narrow the number of emotions and focused on those emotions with great influence value. This referred to [22] that the minimum value based on the number of 200 participants was determined at 0.40 Therefore, out of 30 variables, 7 variables were eliminated so that 23 variables were grouped into 5 factors. In Factor 1, there were 16 emotions, namely Fantastic, Different, Innovative, Wonderful, Unique, New, Funny, Great, Beautiful, Special, Perfect, Good, Protecting, Colorful, Easy, and Local. In Factor 2, there were 2 emotions, namely Colorful and Season. In Factor 3, there were 2 emotions, namely Clear and Beautiful. In Factor 4, there were 2 emotions, namely Simple and Sustainable. In Factor 5 there was 1 emotion, namely Ecofriendly. Subjectively, the emotions in each factor were summarized in such concept as Modern, Local, Natural, Standard, and Ecofriendly. The naming was made independently by the researcher. No specific standards were referred to in naming this concept, it was the words which could represent emotion which were given in naming the concept [23].

Table 10. Dummy variable

\begin{tabular}{ccccccc}
\hline CARD & BDADnLontar & BDABambu & BNMPerEnam & BNMKubus & $\ldots$ & HNnHandle \\
\hline 1 & 1 & 0 & 1 & 0 & $\ldots$ & 1 \\
2 & 1 & 0 & 0 & 1 & $\ldots$ & 0 \\
3 & 0 & 1 & 0 & 1 & $\ldots$ & 0 \\
4 & 0 & 1 & 0 & 0 & $\ldots$ & 0 \\
5 & 0 & 1 & 0 & 0 & $\ldots$ & 0 \\
6 & 0 & 1 & 0 & 1 & $\ldots$ & 1 \\
7 & 1 & 0 & 0 & 0 & $\ldots$ & 1 \\
8 & 0 & 1 & 0 & 0 & $\ldots$ & 1 \\
9 & 0 & 1 & 1 & 0 & $\ldots$ & 0 \\
10 & 1 & 0 & 0 & 0 & $\ldots$ & 0 \\
11 & 1 & 0 & 0 & 0 & $\ldots$ & 0 \\
12 & 0 & 1 & 0 & 0 & $\ldots$ & 0 \\
13 & 0 & 1 & 1 & 0 & $\ldots$ & 1 \\
\hline
\end{tabular}

The obtained statistic data were then analyzed using Partial Least Square (PLS) analysis into design elements based on the related emotions. Hence, a design was obtained according to the emotions existing in the Modern, Local, Natural, Standard, and Ecofriendly concepts. The PLS analysis used XLStat 2020 software. The data involved in this analysis were variable y in the form of data from 30 emotion average recapitulation by 200 participants, variable $\mathrm{x}$ in the form of packaging specimen design element manifested in dummy variable, and 13 packaging specimens. Table 10 is formed from the number of categories studied in this study (19 categories from 7 attributes) as shown in Table 5. The analysis result could be seen in Table 11 . 
Table 11. PLS Result

\begin{tabular}{clcccc}
\hline No & Emotion & BDADnLontar & BDABambu & $\ldots$ & HNnHandle \\
\hline 1 & Sustainable & 0.027 & -0.027 & $\ldots$ & -0.012 \\
2 & Ecofriendly & 0.013 & -0.013 & $\ldots$ & 0.012 \\
3 & Innovative & 0.092 & -0.092 & $\ldots$ & -0.079 \\
4 & Season & 0.016 & -0.016 & $\ldots$ & -0.032 \\
5 & Great & 0.068 & -0.068 & $\ldots$ & -0.069 \\
6 & Efficient & 0.029 & -0.029 & $\ldots$ & -0.025 \\
7 & Handmade & -0.014 & 0.014 & $\ldots$ & 0.036 \\
8 & Safety & 0.029 & -0.029 & $\ldots$ & -0.005 \\
9 & Economic & 0.011 & -0.011 & $\ldots$ & 0.004 \\
10 & Local & 0.073 & -0.073 & $\ldots$ & -0.065 \\
11 & Good & 0.059 & -0.059 & $\ldots$ & -0.047 \\
$\ldots$ & $\ldots$ & $\ldots$ & $\ldots$ & $\ldots$ & $\ldots$ \\
30 & Perfect & 0.064 & -0.064 & $\ldots$ & -0.064 \\
\hline
\end{tabular}

The variables having the values in Table 11 were then categorized by their type and the Range values were sought of each category. The category Range value was sought to figure out the extent of influence of variables (design attribute/ element) on the emotion concepts. The Range values were sequenced from the biggest to the smallest to find out the extent of influence of design elements on the emotion concepts. The category Range was determined in reference to [22].

Table 12. Design concept

\begin{tabular}{cll}
\hline No & Design concept & \multicolumn{1}{c}{ Category } \\
\hline 1 & Sustaninable & PUBKecil \\
& Safesty & BRMOriginal \\
& Natural & BNMPerEnam \\
& Original & PLLSatuSisi \\
& Simple & BNMTabung \\
& Organic & BDADnLontar \\
& & BDLPita \\
& & Hhandle \\
& & BDLWindow \\
2 & Ecofriendly & BNMPouch \\
& Economic & BRMOriginal \\
& Clear & PUBKecil \\
& & BNMPerEnam \\
& & PLLSatuSisi \\
& & BDLWindow \\
& & BNMTabung \\
& & BDADnLontar \\
& & HnnHandle \\
11 & Protecting & BDLPita \\
& & $\ldots$
\end{tabular}




\begin{tabular}{cl}
\hline No $\quad$ Design concept & \multicolumn{1}{c}{ Category } \\
\hline & BNMPerEnam \\
& BRMOriginal \\
& BNMTabung \\
& BDADnLontar \\
& PLLSatuSisi \\
& BDLPita \\
& Hhandle \\
& BNMPouch \\
\hline
\end{tabular}

Table 13 showed that the categories with values above or equal to the average range were those variable which influenced the designing of eco-friendly packaging design for Getuk Goreng based on the emotion concepts. For example, in the "Sustainable" concept, the variables which had influence were Small Size, Original basic Color, Hexagon Shape, tube, and Pouch, One-Side Labelling, Palm Leave Material, Ribbon and Window Accessories, and equipped with Handle. The highest value was in Small Size, meaning this category had a strong effect on the designing of Getuk Goreng packaging design for the "Sustainable" emotion concept. Meanwhile, Handling NonHandle, Interesting Shape, Cube to the last variables below them had lower values than the standard range. It could then be said that these variables had no influence on the designing of "Sustainable" emotion concept design.

Furthermore, the result from the second multivariate analysis was previously used as the basis to make a matrix of the proposed packaging designs. The process of making this proposed matrix referred to the research conducted by [22]. The emotion/kansei words included in the proposed matrix table were summarized in five concepts of Getuk Goreng packaging design, namely Modern, Local, Natural, Standard, and Ecofriendly. The packaging design recommendation given took the shape of a matrix table which was the result of narrowing the matrix of proposed design element of eco-friendly packaging concept for Getuk Goreng based on emotions in Table 13.

Table 13. Recommendation design

\begin{tabular}{|c|c|c|c|c|c|c|c|c|c|}
\hline No & $\begin{array}{l}\text { Concept } \\
\text { Design }\end{array}$ & Emotion & Material & Form & Size & Color & $\begin{array}{c}\text { Label } \\
\text { Placement }\end{array}$ & $\begin{array}{c}\text { Acsessor } \\
\text { ies }\end{array}$ & Handling \\
\hline 1 & Modern & New & $\begin{array}{l}\text { Palm } \\
\text { leaves }\end{array}$ & Hexagonal & Small & Colorful & $\begin{array}{l}\text { Twisted } \\
\text { around }\end{array}$ & $\begin{array}{c}\text { Natural } \\
\text { rope }\end{array}$ & Handle \\
\hline \multirow[t]{2}{*}{2} & Local & Colorfull & $\begin{array}{l}\text { Palm } \\
\text { leaves }\end{array}$ & Cube & Small & Original & One side & Ribbon & Handle \\
\hline & & Season & $\begin{array}{l}\text { Palm } \\
\text { leaves }\end{array}$ & Cube & Medium & Colorful & $\begin{array}{l}\text { Twisted } \\
\text { around }\end{array}$ & $\begin{array}{c}\text { Natural } \\
\text { rope }\end{array}$ & Handle \\
\hline \multirow[t]{2}{*}{3} & Natural & Clear & $\begin{array}{l}\text { Palm } \\
\text { leaves }\end{array}$ & Hexagonal & Small & Original & One side & Window & $\begin{array}{c}\text { No- } \\
\text { handle }\end{array}$ \\
\hline & & Beatiful & $\begin{array}{l}\text { Palm } \\
\text { leaves }\end{array}$ & Hexagonal & Small & Original & $\begin{array}{l}\text { Twisted } \\
\text { around }\end{array}$ & Ribbon & Handle \\
\hline 4 & Standard & Simpel & Palm & Hexagonal & Small & Original & One side & Window & Handle \\
\hline
\end{tabular}




\begin{tabular}{cccccccccc}
\hline No & $\begin{array}{c}\text { Concept } \\
\text { Design }\end{array}$ & Emotion & Material & Form & Size & Color & $\begin{array}{c}\text { Label } \\
\text { Placement }\end{array}$ & $\begin{array}{c}\text { Acsessor } \\
\text { ies }\end{array}$ & Handling \\
\hline & & Sustainable & $\begin{array}{c}\text { leaves } \\
\text { Palm } \\
\text { leaves } \\
\text { Palm } \\
\text { leaves }\end{array}$ & Hexagonal & Small & Original & One side & Ribbon & Handle \\
5 & Ecofriendly & Ecofriendly & Small & Original & One side & Window & $\begin{array}{c}\text { No- } \\
\text { handle }\end{array}$ \\
\hline
\end{tabular}

Moreover, the recommended packaging design based on emotion from the research in Table 13 was actualized into a packaging shape resembling the original through a prototype. The suitable one is the Ecofriendly design with Small Size, Original basic Color, Hexagon Shape, One-Side Labelling, Palm Leave Material, Ribbon and Window Accessories, and without Handle.

\section{Conclusion}

30 customer kansei words were selected in this research, namely Sustainable, Ecofriendly, Innovative, Season, Great, Efficient, Handmade, Safety, Economic, Local, Good, Natural, Different, Clear, Original, Fantastic, New, Traditional, Unique, Simple, Special, Funny, Heavy, Organic, Wonderful, Easy, Beautiful, Protecting, Colorful, and Perfect. A matrix of packaging design recommendation with 5 design concepts, namely Modern, Local, Natural, Standard, and Ecofriendly consisting of 7 packaging design attributes/elements, namely materials, shape, size, basic color, label placing, accessories, and handling was generated. The result show that costumer eager the Getuk Goreng packaging with an eco-friendly concept design. It was made from palm leaves, with the shape of hexagonal, and small in size (netto: 500 gram). The other packaging properties recommended were natural in color, the front side should be equipped with window, and it shouldn't handle.

\section{References}

[1] Utami, P. 2011. Sertifikasi Halal sebagai Upaya Peningkatan Kualitas Produk Olahan Komoditas Pertanian Unggulan Daerah. Jurnal AGRITECH. Vol.13 No.1.

[2] Handayani, I. 2003. Pengembangan Produk Makanan Tradisional untuk Mendukung Program Makanan Tambahan Anak Sekolah. Jurnal Pembangunan Pedesaan. Vol.3 No.2

[3] Nurfaizal, Y. 2015. Analisis Faktor Gaya Kepemimpinan Transformasional dan Transaksional Terhadap Komitmen Tenaga Kerja UMKM yang Dimediasi Kepuasan Kerja. Jurnal Probisnis. Vol.8 No.2.

[4] Kurniawan, I., Syamsu H. \& Wijang S. 2019. Pengaruh Kompetensi Wirausaha, Skala Usaha dan Saluran Pemasaran Terhadap Keberhasilan Usaha. Economic Education Analysis Journal. Vol.8 No.1. 
[5] Watemin \& Pujianti U. 2006. Analisis Nilai Tambah Agroindustri Getuk Goreng di Kecamatan Sokaraja Kabupaten Banyumas. Laporan Penelitian. Fakultas Pertanian, Universitas Muhammadiyah Purwokerto, Purwokerto.

[6] Mu'alim \& Rachmad H. 2014. Re-Desain Kemasan dengan Metode Kansei Engineering. Jurnal AlAzhar Indonesia Seri Sains dan Teknologi. Vol.2 No.4.

[7] Kotler, P. \& Keller, K.L. 2009. Alih Bahasa : Benyamin Molan. Manajemen Pemasaran. Edisi Keduabelas. Jilid 1. Cetakan Keempat. PT. Indeks. Jakarta.

[8] Albino, V., Balice, A., Dangelico, R.M. (2009). Environmental strategies and green product development: an overview on sustainability-driven companies. Business Strategy and the Environment, 8(2), 83-96.

[9] Okada, E.M. \& Mais, E.L. (2010). Framing the green alternative for environmentally conscious consumers, sustainability accounting. Management and Policy Journal. 1 (2), 222-234.

[10] Suherlan, Y., Hermansyah M., Choiroel A. \& Emi W. 2016. Model Balai Pengembangan Kemasan Ramah Lingkungan untuk Meningkatkan Daya Saing Produk Lokal UMKM Pangan Olahan Menghadapi Pasar Global. Prosiding Seminar Nasional Peningkatan Kapabilitas UMKM dalam Mewujudkan UMKM Naik Kelas. Universitas Sebelas Maret, Surakarta.

[11] Johannes, Suswita R. \& Ilunitedra. 2015. Pengaruh Green Product Terhadap Brand Image Produk Air Minum Dalam Kemasan Merek Aqua. Digest Marketing. Vol. 1 No.1.

[12] Lesmana, P. I. 2013. Analisis Sentimen Pengguna Layanan Media Sosial Twitter di Indonesia. Tugas Akhir. Fakultas Ilmu Komputer, Universitas Indonesia, Jakarta.

[13] Puspitadewi, I., Wina E. \& Nuning K. 2016. Pemanfaatan “TWITTER TMCPOLDMETRO” dalam Memenuhi Kebutuhan Informasi Para Pengguna Jalan Raya. Jurnal Kajian Informasi \& Perpustakaan. Vol.4 No.1.

[14] Schutte S. 2002. Deingning Feelings into Products: Integrating kansei engineering methodology in product Development. Thesis. Department of Mechanical Engineering, Linköpings universitet, Linköpings.

[15] Nagamachi, M. \& Anitawati M. L. 2003. Inovatons of Kansei Engineering. Taylor \& Francis Group, Tokyo.

[16] Tama, I.P., Azlia, W. \& Hardiningtyas, D. 2015. Development of costumer oriented product design using Kansei Engineeringand Kano model: case study of ceramic souvenir. Procedia Manufacturing. 4: 328-225.

[17] Kusumo, A.H., Hartono, M., \& Wahyudi, R.D. 2019. Product design with integration of kansei engineering and TRIZ to promote sustainable tourism. AIP Conference Proceedings.

[18] Wirawan, V., Seng H. \& Hargyo T.N. 2014. Implementasi Algoritma Squeezer dan Term Frequency Ranking dalam Pembangunan Sistem Rekomendasi Tempat Makan. Jurnal ULTIMA Computing. Vol. 06 No. 01.

[19] Fitriani, S.B. 2019. Analisis Perilaku Produk Ramah Lingkungan. 1. Fakultas Ekonomi dan Bisnis, Universitas Muhammadiyah Surakarta, Surakarta.

[20] Hardiningtyas, D., Ishardita P.T., Agustina E. \& Debrina P.A. 2016. Studi Faktor Kansei pada Produk Berbasis Kearifan Lokal (Studi Kasus: Batik Malanga). JEMIS. Vol.04 No.02.

[21] Badaruddoza, Raman K. \& Manpreet K. 2015. Principal Component Analysis of Cordiovascular Risk Traits in Three Generations Cohort Among Indian Punjabi Population. Journal of Advanced Reseacrh (2015) 6, 739-746.

[22] Isa, I.G.T. \& Ana H. 2017. Implementasi Kansei Engineering dalam Perencanaan Desain Interface E-Learning Berbasis Web (Studi Kasus: SMK Negeri 1 Sukabumi). Jurnal Teknik Iformatika dan Sistem Informasi. Vol.3 No.1. 
[23] Hair, J.F., William C.B., Barry J.B. \& Rolph E.A. 2014. Multivariate Data Analysis Pearson New International Edition Seventh Edition. Pearson, United States of America. 